\title{
Y kuşağı gençliğinin yaşlılık ve yaşlanmaya ilişkin tutumları: Nevşehir örneği ${ }^{1}$
}

\author{
Hamza KURTKAPAN 2
}

Nevșehir Hacı Bektaș Veli Üniversitesi, Sağlık Hizmetleri MYO, Nevșehir, Türkiye

ORCID No: https://orcid.org/0000-0001-9815-7337/

\section{ÖZET}

Türkiye'de yaşlı nüfusun genel nüfus içerisindeki oranı hızla artmaktadır. 2060 yılında, Türkiye'de yaşayan her beş kişiden birinin yaşlı olacağı ön görülmektedir. Günümüzde 20'li yaşlarını deneyimleyen gençler, 2060'lı yıllarda yaşlılığa adım atacaklardır. Türkiye'nin 21. yy.'in ikinci yarısına iliskin yaşlılık politikaları, bu dönemde yaşlılığa adım atacak olan $Y$ kuşağının özellikleri ve tutumları göz önünde bulundurularak yapılmalıdır. Türkiye'de Y kuşağg ile ilgili pek çok çalışma yapılmış ancak onların yaşlılık ve yaşlanma ile ilgili tutumlarına yeteri kadar bakılmamıștır. Bu çalışsma, Y kuşağına mensup 19-24 yas grubundaki gençlerin, yaşlılık ve yaşlanmaya iliş̧in tutumlarını belirlemeyi amaçlamaktadır. Araștırmanın evrenini, Nevșehir Hacı Bektaş Veli Üniversitesinde 2018-2019 Ĕ̈itim ve Öğretim Yılı Bahar Güz Dönemine kayıtı lisans öğrencileri olușturmaktadır. Calışmada, araştırmaya katılan gençlerin yașlılık ve yașlanmaya ilișkin görece olumsuz bir tutuma sahip oldukları tespit edilmiștir. Katılımcıların yaşlılık ve yaşlanmaya ilişskin tutumlarının cinsiyet, yaşanılan yer, aile tipi ve büyük ebeveynler ile birlikte yașama değisskenlerine göre anlamlı bir düzeyde değișmediği görülmüsstür. Ancak büyük ebeveynler ile geçirilen sürenin, yaşlllık ve yaşlanmaya ilişsin tutumu olumsuz etkilediği tespit edilmiștir. Çalışmada, yaşlanmaya ilişsin olumlu tutumun, yaşl bireyler ile ileride çalışma arkadaşı olma isteğine olumlu yansıdığı belirlenmiștir. Ayrıca yaş̧ı bakımında devlet yerine aileye öncelik veren katılımcılarda, daha olumlu bir yaşlllık ve yaşlanma tutumu tespit edilmiștir.

\section{Attitudes of generation $Y$ towards old age and aging: The case of Nevşehir}

\begin{abstract}
The rate in the general population, the elderly population is increasing rapidly in Turkey. In 2060, it is estimated that one out of every five elderly people will be living in Turkey. Young people who experience their 20s today will step into old age in the 2060s. Aging policy regarding Turkey in the second half of the 21st century should be made by taking into consideration characteristics and attitudes of Generation $Y$ who will step into old age during this period. A lot of work related to Generation $Y$ made in Turkey, but not considered enough on their attitudes about their old age and aging. This study aims to determine the attitudes of young people in the Y generation between the ages of 19-24 regarding aging and aging. The population of the research consists of undergraduate students enrolled in Nevșehir Hacı Bektas Veli University in the 2018-2019 Academic Year Fall Semester. In the study, it was determined that the young people participating in the research had a relatively negative attitude towards old age and aging. It was observed that the attitudes of the participants regarding old age and aging did not change significantly according to the variables of gender, place of residence, family type and living with grandparents. However, it was found that the time spent with grandparents negatively affected the attitude towards old age and aging. In the study, it was determined that the positive attitude towards aging reflected positively on the desire to become a colleague with older individuals in the future. In addition, a more positive old age and aging attitude was determined in the participants who prioritize the family rather than the state in elderly care.
\end{abstract}

\section{ARTICLE HISTORY}

Received 19 Feb. 2020

Accepted 15 June 2020

\section{KEYWORDS}

Sociology of aging, age stratification, generation $Y$, attitude scale

\section{GIIRIS}

Ulusal ve uluslararası kuruluşların raporlarına göre, Türkiye'de nüfus giderek yaşlanmaktadır (United Nati- ons Department of Economic and Social Afairs [UNDESA], 2015; Türkiye İstatistik Kurumu [TÜIKK], 2018). Türkiye'de 2000 yılında 3,6 milyon olan 65 yaş ve üzeri nüfus, 2018 verilerine göre 7 milyonu aşmıștır. 2060

\footnotetext{
${ }^{1}$ Makalenin Kaynak Olarak Gösterimi: Kurtkapan, H. (2020). Y kuşağı gençliğinin yaşlılık ve yaşlanmaya ilişkin tutumları: Nevşehir örneği. Yaşl Sorunları Araştırma Dergisi (YSAD), 13(1), 48-55.

${ }^{2}$ Sorumlu Yazar e-mail: hamzakurtkapan@nevsehir.edu.tr
} 
yılında ise bu sayının 24 milyona ulaşacağı ön görülmektedir. Böylece nüfusun beşte birinden fazlasının 65 yaş ve üzeri bireylerden oluşacağı hesaplanmaktadır. Ayrıca 2055-2065 yılları arasındaki bu dönemde toplam nüfus içerisinde 65 ve üzeri yaştakilerin oranının, ilk defa 0-14 yaş grubundaki çocukların oranından fazla olacağı ön görülmektedir ${ }^{3}$ (TÜİK, 2019). 65 yaş ve üzeri nüfusun bu dönem için beklenen sayısal ve oransal fazlalığı, geliștirilecek sosyal politika için de belirleyici olmalıdır. 2055-2065 yılları arasında yaşlılığı deneyimleyecek nüfusa yönelik özel bir çalışma yapılması gereklidir. Böylesi bir çalışmanın hazırlığı olarak ise 21. yüzyılın ortalarında yaşlılığa adım atacak olan Y kuşağı ${ }^{4}$ mercek altına alınmalıdır.

Türkiye'nin 2060'larda deneyimleyeceği nüfus oranı dağılımına çoğu gelişmiş ülke 2010'lu yıllarda ulașmıștır. Örneğin, Kanada'da ilk defa 2015 yılında yaşlıların toplam nüfus içerisindeki oranı, 15 yaş altı çocuklarınkini geçmiştir. Gelişmiş ülkelerde bu duruma hazırlık olarak, söz konusu nüfus dağılımına ulaşılmadan önce 2010 'lu yıllarda yașlılığa adım atacak olan "baby boomer" kuşağı hakkında çalışmalar yapılmıştır. Bundan dolayı gelişmiş ülkelerde, yaşlılık sosyolojisinin çeyrek yüzyıllık tarihinde yașlılık araștırmalarının merkezinde "baby boomer" kuşakla ilgili çalışmalar önemli bir yer tutmaktadır.

Gelișmiș ülkelerin 2000'li yılların bașında yașadıkları bu tarihsel evreyi, Türkiye'nin 21. yy.'ın ikinci yarısında yașayacağı ön görülmektedir (TÜİK, 2018). Bundan dolayı gelișmiș ülkelerde "baby boomer" kuşağına gösterilen ilginin Türkiye'de 2060'lı yıllarda yaşlılığa ilk adımı atacak olan "Y kuşağına" gösterilmesi gereklidir. 1990-99 yılları arasında doğan ve günümüz gençlerini oluşturan bu kuşak Türkiye'de kritik bir tarihsel evrede yașlılığa başlamıș olacaktır. Yukarıda da bahsedildiği gibi Türkiye'de 2060 yılına gelmeden yaşlıların nüfus içerisindeki oranı, çocukların oranından fazla olacağı ön görülmektedir.

Bu çerçevede Türkiye'de 1990'lı yıllarda doğan ve Y kuşağı olarak adlandırılan gençlerin yaşlılığa ilişkin beklenti, istek ve tutumlarına bakmak gerekmektedir (Kurtkapan, 2019:168). Bu gençlerin yaşlılıkla ilgili sosyal meseleleri nasıl algıladıkları ve yaşlıların sosyal yaşamdaki konumları hakkındaki görüşleri önemlidir. Yaşlılık sosyolojisindeki, "yaş tabakalaşması" kuramına göre, her dönemin yașlılarının özellik, beklenti, tutum ve algıları önceki dönemlerin yaşlılarından farklıdır. Riley tarafından, 1971 yılında, geliștirilen "yaș tabakalaşması" kuramına göre, belli bir yaş grubuna mensup bireyler toplumdaki önemli sosyal ve ekonomik etkilere aynı yașlarda maruz kalmakta ve bu da onların ortak özelliklere sahip olmalarına neden olmaktadır. Örneğin, bir ekonomik krizden, bu krizi onlu yașlarında yaşayanlar ile otuzlu yaşlarında yaşayanlar farklı

Araștırma evrenini Nevșehir Hacı Bektaș Veli Üniversitesinde 2018-2019 güz dönemine kayıtll, 19-24 yaş

\footnotetext{
3 Türkiye İstatistik Kurumu verilerine göre, 2060 yllında 107.095.998'e ulaşması ön görülen toplam nüfus içerisinde, 0-14 yaș grubundakilerin sayısı $18.126 .086(\% 16,9)$, 65 ve üzeri yaş grubundakilerin sayısı ise $24.242 .787(\% 22,6)$ olarak ön görülmektedir (TÜiK, 2019).
}

biçimde etkilenmektedir. Benzer deneyimleri aynı yaşlarında yașayanlar arasında benzer alıșkanlık ve özellikler gelişmektedir. Bu durum, kimi zaman aynı kuşaktakilerde bir alt kültür olușturacak kadar önemli seviyelere çıkabilmektedir. Örneğin, küreselleşmenin sık sık dile geldiği bir dönemde doğan ve büyüyen Y kuşağında da kendine özgü bir alt kültür geliștiği görülmektedir.

Bu kuşak; küresel iklim, tüketim kültürü, küresel çevre kirliliği gibi etkenler ile büyümektedir. Bu etkenler, Y kuşağına mensup olan gençlerin yaşlılık ve yaşlanmaya ilişkin tutumları üzerinde de etkili olmaktadır. Yaşlılık ve yaşlanma algısı her ne kadar kişisel bir durumu ifade etse de sosyalleşme süreçlerinden bağımsız değildir (Kurtkapan, 2018). Bundan dolayı yaşlılık ve yaşlanmaya ilişkin tutumu belirleyen sosyo-ekonomik ve kültürel faktörler de önemli olmaktadır. 1980’li yıllar, neo-liberal politikaların egemen olduğu ve sosyal devletin küçüldügü, girişimciliğin önemsendiği bir dönemdir (Kökalan-Çımrın, 2009: 199). Bu faktörlerin yaşlılık ve emeklilik politikaları üzerindeki yansımaları bu dönemde doğup büyüyen $Y$ kuşağının yaşlılık ve yaşlanma algısı üzerinde etkili olmaktadır.

Bilgisayar, internet ve cep telefonu teknolojilerinin içine doğan Y kuşağı için küreselleşme, google, msn, cep telefonu önemli belirleyicilerdir. Bayhan (2014)'a göre Y kuşağının temel özelliği "sorgulayıcı" ve "yaratıcı" olmalarıdır. Bu kuşağa mensup bireylerin hayatlarında rahatlık önemlidir. Çalıșmayı severler ancak hayatı sadece ișten ibaret görmek istemezler (Bayhan, 2014: 14). Bu özellikler onların yaşlılık ve yaşlanmaya ilișkin tutumlarını da belirlemektedir. Zira teknoloji ve iletișim olanakları, onları önceki kuşaklardan daha fazla bireyci yapmaktadır. Buna rahatlı̆̆ sevmeleri de eklenince yaşlılara karşı daha az tahammülleri olmaktadır. Bu özellikler, onların yaşlı ayrımcılığı ve yaşlı bakımı gibi pek çok konuda daha olumsuz bir tutum geliştirmelerine sebep olmaktadır.

Tüm bunlardan hareketle bu çalışmada, 19-24 yaş aralığındaki bir grup gencin yaşlılık ve yaşlanmaya ilişkin tutumlarını ortaya çıkarmak amaçlanmıștır. Gençlerin tutumları üzerinde etkisi olabilecek demografik ve sosyal değișkenlere bakılmıștır. Ayrıca araștırmaya katılan gençlerin meslek yaşamlarında yaşlılar ile birlikte çalışmayı isteyip istememeleri ve yaşlı bakımına ilişkin görüşleri çalışmaya dahil edilmiştir.

\section{MATERYAL VE YÖNTEM}

Nicel araștırma yöntemi kullanılan bu kesitsel çalıșmada, gençlerin yaşlılık ve yaşlanmaya ilişkin tutumları sosyal ve demografik faktörler dikkate alınarak incelenmektedir. Çalışmada tarama modeli kullanılmıştır. Tarama modelinde var olan bir durum olduğu gibi betimlenmeye çalıșılmaktadır (Karasar, 1998). aralığındaki lisans öğrencileri oluşturmaktadır. Araştırmanın örneklem grubunu oluşturan 639 katılımcl,
${ }^{4}$ Dünya literatüründe 1980-2000 yılları arasında doğanlar Y kușağı olarak adlandırılmaktadır. Ancak Bayhan, Türkiye'de teknoloji ve iletişim araçları ile geç tanışmanın bir sonucu olarak, bu kuşağın 1990- 2000 yılları arasında doğanları kapsaması gerektiğini belirtmektedir (Bayhan, 2014:14). 
basit rastgele örneklem yöntemi ile seçilmiştir. Katılımcllara ait demografik bilgiler, Tablo-1'de gösterilmektedir.

Tablo1. Katılımcıların demografik özellikleri (N=639)

\begin{tabular}{|c|c|c|}
\hline Cinsiyet & $\mathrm{f}$ & $\%$ \\
\hline Kadın & 451 & 70,6 \\
\hline Erkek & 188 & 29,4 \\
\hline \multicolumn{3}{|c|}{ Doğduğu, büyüdüğü yer } \\
\hline Kır & 217 & 34,0 \\
\hline Kent & 417 & 64,3 \\
\hline Cevap yok & 5 & 0,8 \\
\hline \multicolumn{3}{|c|}{ Ailenin aylkk ortalama geliri } \\
\hline $0-1700 \mathrm{TL}$ & 138 & 21,6 \\
\hline $1701-2200 \mathrm{TL}$ & 132 & 20,7 \\
\hline $2201-3250 \mathrm{TL}$ & 136 & 21,3 \\
\hline $3250+\mathrm{TL}$ & 139 & 21,8 \\
\hline Cevap yok & 94 & 14,6 \\
\hline \multicolumn{3}{|l|}{ Aile Tipi } \\
\hline Çekirdek Aile & 554 & 86,7 \\
\hline Geniş Aile & 73 & 11,4 \\
\hline Cevap yok & 12 & 1,9 \\
\hline \multicolumn{3}{|c|}{ Büyük ebeveynler ile aynı evde birlikte yaşama durumu } \\
\hline Evet & 301 & 47,1 \\
\hline Hayır & 333 & 52,1 \\
\hline Cevap yok & 5 & 0,8 \\
\hline \multicolumn{3}{|c|}{ Büyük ebeveynler ile birlikte yaşama süresi (N=301) } \\
\hline $1-5$ yll & 90 & 29,9 \\
\hline 6-23 yıl & 126 & 41,9 \\
\hline Cevap yok & 85 & 28,2 \\
\hline \multicolumn{3}{|c|}{60 Yaş Üstü Bireyle Birlikte Çalışmayı İsteme Durumu } \\
\hline Evet & 318 & 49,8 \\
\hline Hayır & 316 & 49,5 \\
\hline Cevap yok & 5 & 0,7 \\
\hline \multicolumn{3}{|c|}{ Yaşlı Bakımı Kimin Sorumluluğunda Olmalı } \\
\hline Devlet & 128 & 20,0 \\
\hline Aile & 371 & 58,1 \\
\hline Cevap yok & 140 & 21,9 \\
\hline
\end{tabular}

Tablo 1'de görüleceği üzere, araștırmaya katılanların \% 70,6'sı kadın, \% 29,4'ü erkektir. Katılımcıların \% 64,3'ü kent, \% 34,0'ü ise kır/köy doğumludur. Katılımclların \% 42,3'ü ailelerinin ortalama aylık gelirinin 2201 TL'den düşük olduğunu belirtmiștir. Katılımcıların \% 86,7'si çekirdek ailede, \% 11,4'ü ise geniș ailede doğup büyüdüklerini ifade etmiștir. Katılımcıların \% $47,1^{\prime} i$ ise yașamlarında altı aydan fazla bir süre büyük ebeveynler ile birlikte aynı evde yaşadıklarını belirtmiştir.

\subsection{Veri Toplama Aracı}

Araştırmanın veri toplama aracı olan anket formu iki bölümden oluşmaktadır. Formun ilk bölümünde kișisel bilgiler, ikinci bölümünde ise Yaşlanma ve Yaşlılığa Illişkin Tutum Ölçeği [YYTÖ]yer almaktadır. Ankette, katılımcların yaşını, cinsiyetini, gelir düzeyini belirlemeye yönelik soruların yanında, gençlerin ailelerine ilișkin sorular da bulunmaktadır. Araştırmanın verileri sınıf ortamında, araştırmacının gözetiminde, katılımcılar tarafından anket formunun doldurulması şeklinde elde edilmiştir.

2.2. Yaşlılık ve Yaşlanmaya İlişkin Tutum Ölçeği [YYTö]

Ankette, Otrar'ın geliștirdiği 45 maddeden oluşan "Yaşlllık ve Yaşlanmaya IIlişskin Tutum Ölçeği (YYTö)" kullanılmıștır (2016). Bu ölçek, 18 yaș üzeri bireylerin yașlılık ve yaşlanmaya ilişkin tutumlarını belirlemeyi amaçlayan, 5'li likert tipi bir ölçektir. Ölçeği kullanabilmek için ölçeği geliştiren araştırmacıdan e-posta yoluyla izin alınmıştır. Otrar, ölçeğin Cronbach Alfa güvenirlilik katsayısını 0,97 olarak hesaplamıștır (Otrar, 2016: 527). Bu araştırmada, benzer biçimde, ölçeğin güvenirlilik katsayısı 0,92 olarak hesaplanmıștır. YYTÖ ölçeğinden alınabilecek en düşük puan 45 iken, en yüksek puan 225 'tir. Ölçek toplamda 4 alt boyuttan oluşmaktadır. Birinci alt boyut olan "Yaşlılığı Kabullenme Zorluğu"ndan (12 Madde) en düşük 12, en yüksek 60 puan alınabilmektedir. İkinci alt boyut olan "Sosyal Yıpranma Algısı"ndan (15 madde) en düşük 15, en yüksek 75 puan alınabilmektedir. Üçüncü alt boyut "Yaşamla Baş Etme Zorluğu"ndan (10 madde) en düşük 10 , en yüksek 50 puan alınabilmektedir. "Olumsuz İmge" (8 madde) olarak isimlendirilmiş olan dördüncü alt boyuttan ise 8 ile 40 arasında puan alınabilmektedir (Otrar, 2016:536). Ölçekten elde edilen genel toplam puanın yükselmesi genel olarak olumsuz tutumun yükseldiği, puanın düşmesi ise yaşlılığa ilişkin olumlu tutum ve algının yükseldiği șeklinde yorumlanmaktadır. Ayrıca katılımcının ölçeğin alt boyutlarından aldığı puan yükseldikçe, ilgili tutum da olumsuz yönde güçleniyor șeklinde yorumlanmaktadır (Otrar, 2016: 535). Örneğin, katılımcının "yaşlılığı kabullenme zorluğu” alt boyutundan yüksek puan alması, onun yașlılığı kabullenmede zorluk yaşadığını göstermektedir.

\subsection{Anket Formunun Uygulanması}

Araștırma öncesinde Nevșehir Hacı Bektaș Veli Üniversitesi Etik Kurulundan 16.01.2019/1 karar numaralı onay raporu alınmıştır. Ayrıca araştırmanın yapıldığı Fakülte yönetimleri ve katılımcılardan gerekli izinler alınmıștır. Anketin işlerliğini test etmek üzere, 15 gönüllüyle pilot uygulama yapılmıștır. Pilot uygulama sonrası ankette gerekli düzeltmeler yapılmıștır. Anket, 15 Şubat-10 Mart 2019 tarihleri arasında uygulanmıștIr. Verilerin analizinde, SPSS 25.0 programından yararlanılmıştır. Ölçekte yer alan 30., 32. ve 43. maddeler ters çevrilerek yeniden kodlanmıștır (Otrar, 2016). Verilerin değerlendirilme aşamasında tanımlayıcı istatistik metotlarından yararlanılmıștır. İstatistiksel veriler değerlendirilirken frekans ve bağımsız gruplar t-Testi analizlerinden yararlanılmıştır. Bulgular, \%95 güven aralığında değerlendirilmiştir.

\section{BULGULAR}

Bu bölümde, 19-24 yaș arası 639 katılımcıya uygulanan anketten elde edilen verilerin analizlerine yer verilmektedir. Öncelikle, katılımcıların Yaşlılık ve Yaşlanmaya İlişkin Tutum Ölçeğınden (YYTÖ) aldıkları puanlar analiz edilmiştir. Sonrasında katılımcıların yaşlılık ve yașlanmaya ilișkin tutumlarını etkileyen cinsiyet, aile tipi, yerleşim yeri ve büyük ebeveynleri ile birlikte aynı evde yaşama durumları, gruplar homojen dağılım gösterdikleri için bağımsız gruplar t-Testi ile analiz edilmiştir. Ayrıca katılımcıların yaşlı çalışanlar ve yaşlı 
bakımı hakkındaki görüşleri de analize dahil edilmiştir. Bu doğrultuda katılımcıların YYTÖ ölçek puanları ile yaşlı ile çalışmayı isteyip/istememe durumları ve yaşlı bakımı sorumlusuna ilişkin görüşleri arasındaki ilişki, bağımsız gruplar t-Testi ile analiz edilmiştir.

\subsection{Katılımcıların Yaşlılık ve Yaşlanmaya İlişskin Tutum-} lari
Katılımcıların YYTÖ'den ve bu ölçeğin "Yaşlılı̆̆ı Kabullenme Zorluğu", "Sosyal Yıpranma Algısı", "Yașamla Baş Etme Zorluğu" ve "Olumsuz İmge" alt boyutlarından aldıkları ortalama, minimum ve maksimum puanlar hesaplanmış ve Tablo 2'de gösterilmiştir.

Tablo 2. Katılımcıların Yaşlılık ve Yaşlanmaya İlişkin Tutum Ölçeği [YYTÖ] ve bu ölçeğin alt boyutlarından aldıkları puan ortalamaları $(\mathrm{N}=639)$

\begin{tabular}{llllll}
\hline $\begin{array}{l}\text { Yaşlılık ve Yaşlanmaya İlişkin Tutum Ölçeğinin } \\
\text { [YYTÖ] Alt Boyutları }\end{array}$ & $\mathbf{N}$ & Ort. & Ss. & Min & Max. \\
\hline Yaşlılığı kabullenme zorluğu & 639 & 32,53 & 8,47 & 12 & 57 \\
Sosyal yıpranma algısı & 639 & 41,51 & 8,38 & 17 & 68 \\
Yaşamla baş etme zorluğu & 639 & 31,12 & 7,10 & 10 & 50 \\
Olumsuz imge & 639 & 23,13 & 4,92 & 10 & 39 \\
\hline
\end{tabular}

Tablo 2'de görüleceği üzere katılımcıların, YYTÖ'den ortalama $128,39 \pm 25,28$ puan aldıkları tespit edilmiştir. Katılımcıların yașlılık ve yaşlanmaya ilișkin tutum ölçeğinin "Yaşlılığı Kabullenme Zorluğu" alt boyutunun ortalaması 32,53 $\pm 8,47$ iken, "Sosyal Yıpranma Algısı" alt boyutunun ortalaması 41,51 $\pm 8,38$ 'dir. "Yaşamla Baş Etme Zorluğu" alt boyutunun puan ortalaması $31,12 \pm 7,10$ iken, "Olumsuz İmge" alt boyutunun puan ortalaması 23,13 $\pm 4,92$ 'dir. Bu araștırmada 19-24 yaș grubundaki gençlerin yaşlılık ve yaşlanmaya ilişsin orta düzeyin bir miktar üzerinde olumsuz bir tutuma sahip oldukları tespit edilmiștir.

\subsection{Katılımcıların Yaşhlık ve Yaşlanmaya İlişkin Tutum- larını Etkileyen Faktörler}

Tablo 3. Yaşlılık ve Yaşlanmaya İlişkin Tutum Ölçeğinin (YYTÖ) katılımcıların cinsiyet, aile tipi, doğduğu ve büyüdüğü yerleşim yeri (kır/kent), büyük ebeveynleri ile aynı evde birlikte yaşama durumu değişkenlerine göre farklılaşıp farklılașmadığını belirlemek üzere yapılan bağımsız gruplar t- testi sonuçları

\begin{tabular}{|c|c|c|c|c|c|c|c|c|}
\hline & \multirow{2}{*}{ Değişkenler } & \multirow{2}{*}{$\mathbf{N}$} & \multirow{2}{*}{$\overline{\mathrm{X}}$} & \multirow{2}{*}{ Ss } & \multirow{2}{*}{ Sx } & \multicolumn{3}{|c|}{ t Testi } \\
\hline & & & & & & $\mathrm{t}$ & Sd & $\mathrm{p}$ \\
\hline \multirow{2}{*}{ Cinsiyet } & Kadın & 451 & 128,2 & 24,36 & 1,14 & $-0,214$ & 637 & 0,81 \\
\hline & Erkek & 188 & 128,7 & 27,41 & 1,99 & & & \\
\hline \multirow{2}{*}{ Aile Tipi } & Çekirdek Aile & 554 & 127,9 & 25,74 & 1,09 & $-1,33$ & 625 & 0,18 \\
\hline & Geniș Aile & 73 & 132,1 & 22,75 & 2,66 & & & \\
\hline \multirow{2}{*}{ Yerleşim Yeri } & Kır & 217 & 130,3 & 25,89 & 1,75 & $-1,60$ & 632 & 0,10 \\
\hline & Kent & 417 & 127,0 & 24,79 & 1,21 & & & \\
\hline \multirow{2}{*}{$\begin{array}{l}\text { Büyük ebeveynler ile bir- } \\
\text { likte aynı evde yaşama } \\
\text { durumu }\end{array}$} & Evet & 301 & 128,5 & 24,78 & 1,42 & 0,95 & 632 & 0,92 \\
\hline & Hayır & 333 & 128,3 & 25,53 & 1,39 & & & \\
\hline \multirow{2}{*}{$\begin{array}{l}\text { Büyük ebeveynler ile bir- } \\
\text { likte aynı evde yaşama } \\
\text { süresi }\end{array}$} & $1-5$ yll & 90 & 125,0 & 25,97 & 2,73 & $-2,16$ & 214 & $0,032^{*}$ \\
\hline & $6-23$ yll & 126 & 132,4 & 24,01 & 2,13 & & & \\
\hline
\end{tabular}

${ }^{*} \mathrm{p}<0,05$

Tablo 3'de görüldüğü üzere katılımcıların YYTÖ ölçeği puan ortalamalarının cinsiyet değişkenine göre anlamlı bir farklılık gösterip göstermediğini belirlemek amacıyla gerçekleştirilen bağımsız gruplar t-Testi sonucunda, grupların aritmetik ortalamaları arasında, istatistiksel olarak anlamlı bir fark bulunmamıștır $(\mathrm{t}=-$
3.2.1. Analiz 1. Katılımcıların Cinsiyet, Aile Tipi, Dŏgduğu Büyüdüğü Yerleșim Yeri, Büyük Ebeveynleri ile Aynı Evde Birlikte Yaşama ve Bu Birlikteliğin Süresi değişkenlerine göre Yaşlılık ve Yaşlanmaya İlişkin Tutumları

Gençlerin YYTÖ ölçeğinden aldıkları puanın cinsiyet, yaş, aile tipi, doğduğu büyüdüğü yerleşim yeri (kır/kent), büyük ebeveynleri ile aynı evde birlikte yaşama ve bu birlikteliğin süresi değişkenlerine göre farklılaşıp farklılaşmadığını tespit etmek için bağımsız gruplar t-Testi yapılmıştır. Analiz sonuçları Tablo 3'de gösterilmiştir. 
aynı evde birlikte yaşamaları $(\mathrm{t}=0,95 ; \mathrm{p}=0,92$ $\mathrm{p}>0,05$ ), onların yaşlılık ve yaşlanmaya ilişkin tutumları üzerinde istatistiksel olarak anlamlı bir fark oluşturmamıștır. Diğer taraftan katılımcıların büyük ebeveynleri ile geçirdikleri süre ile yaşlılık ve yaşlanmaya ilişkin tutumları arasındaki fark, istatistiksel olarak anlamlı bulunmuştur $(t=-2,16 ; p<0,05)$. Büyük ebeveynler ile aynı evde birlikte yaşanılan sürenin artması, yaşlılık ve yaşlanmaya ilişkin tutumu da olumsuz etkilemektedir.
3.2.2. Analiz 2. Katılımcıların Aile Tipi ve Doğup Büyüdükleri Yerleşim Yeri Değişkenlerine Göre, YYTÖ Ölçeğinin "Yaşamla Baş Etme Zorluğu" ve "Olumsuz Imge" Alt Boyutlarına Ilișkin Tutumları

Katılımcıların YYTÖ ölçeğinin "Yaşamla Baş Etme Zorluğu" ve "Olumsuz İmge" alt boyutlarından aldıkları puan ortalamalarının aile tipine ve doğup büyüdükleri yerleșim yerlerine göre değișip değișmediğine bakılmıştır. Analiz sonuçları Tablo 4'de gösterilmiștir.

Tablo 4. YYTÖ Ölçeğinin, yaşamla baş etme zorluğu ve olumsuz imge alt boyutlarının katılımcıların aile tipi, doğduğu ve büyüdüğü yerleşim yeri (kır/kent) değişkenlerine göre farklılaşıp farklılaşmadığını belirlemek üzere yapılan bağımsız gruplar t- testi sonuçları

\begin{tabular}{|c|c|c|c|c|c|c|c|c|}
\hline & \multirow{2}{*}{ Değişkenler } & \multirow{2}{*}{$\mathbf{N}$} & \multirow{2}{*}{$\overline{\mathbf{X}}$} & \multirow{2}{*}{ Ss } & \multirow{2}{*}{ Sx } & \multicolumn{3}{|c|}{ t Testi } \\
\hline & & & & & & $\mathrm{t}$ & Sd & p \\
\hline & \multicolumn{8}{|c|}{ YYTÖ Ölçeğinin “Yaşamla Baş Etme Zorluğu” Alt Boyutu } \\
\hline \multirow[t]{2}{*}{ Aile Tipi } & Çekirdek Aile & 554 & 31,00 & 7,22 & 0,39 & $-2,30$ & 100,3 & $0,023 *$ \\
\hline & Geniș Aile & 73 & 32,79 & 6,12 & 0,71 & & & \\
\hline Yerleşim & Kır/köy & 217 & 32,01 & 7,16 & 0,48 & $-2,23$ & 632 & $0,026^{*}$ \\
\hline \multirow[t]{2}{*}{ Yeri } & Kent & 417 & 30,69 & 7,02 & 0,34 & & & \\
\hline & \multicolumn{8}{|c|}{ YYTÖ Ölçeğinin “Olumsuz İmge” Alt Boyutu } \\
\hline \multirow[t]{2}{*}{ Aile Tipi } & Çekirdek Aile & 554 & 23,00 & 4,91 & 0,20 & $-2,25$ & 625 & $0,024^{*}$ \\
\hline & Geniș Aile & 73 & 24,38 & 4,92 & 0,57 & & & \\
\hline Yerleşim & Kır/Köy & 217 & 23,33 & 5,07 & 0,34 & $-0,87$ & 632 & 0,382 \\
\hline Yeri & Kent & 417 & 22,97 & 4,83 & 0,23 & & & \\
\hline
\end{tabular}

${ }^{*} \mathrm{p}<0,05$

Tablo 4'de görüldüğü üzere, çekirdek ailede büyüyen katılımcılar ile geniș ailede büyüyen katılımcıların, YYTÖ ölçeğinin hem "Yaşamla Baş Etme Zorluğu" alt boyutu hem de "Olumsuz İmge" alt boyutlarından aldıkları puanların ortalamaları arasındaki fark istatistiksel olarak anlamlı bulunmuştur. Geleneksel geniş ailede yetișen katılımcıların "Yaşamla Baş Etme Zorluğu" tutumlarının, çekirdek ailede yetişen katılımclara oranla daha yüksek olduğu tespit edilmiștir $(t=-2,30$; $\mathrm{p}=0,023 ; \mathrm{p}<0,05)$. Benzer şekilde geniș ailede büyüyen katılımcıların yașlılığa ilișkin "Olumsuz İmge" tutumları, çekirdek ailede doğmuș ve büyümüș katılımcllara oranla daha yüksektir $(\mathrm{t}=-2,25 ; \mathrm{p}=0,024$; $\mathrm{p}<0,05)$.

Ayrıca yerleşim yerleri kır/köy olan katılımcılar ile doğma büyüme kentli olan katılımcıların "Yaşamla Baș Etme Zorluğu" alt boyutundan aldıkları puanların ortalamaları arasındaki fark istatistiksel olarak anlamlılık göstermektedir $(\mathrm{t}=-2,23 ; \mathrm{p}=0,026 ; \quad \mathrm{P}<0,05)$. Kır/köyde yașayan katılımcıların kente yașayan katılımcılara oranla "Yașamla Baș Etme Zorluğu" alt boyutunda, daha yüksek puan ortalamalarına sahip oldukları tespit edilmiștir. Diğer bir ifade ile kır/köyde yașayan katılımcıların kentte yaşayan katılımcılara oranla daha olumsuz bir yaşamla baş etme zorluğu tutumuna sahip oldukları belirlenmiștir.

\subsubsection{Analiz 3: Yaşlılık ve Yaşlanmaya İlişkin Tutumun} Sosyal Yansimaları

Yaşlılık ve yaşlanmaya ilişkin olumsuz tutumun temelde bir takım sosyal yansımaları olmaktadır. Buna dair bulgular için katılımcıların okul sonrası çalışma yaşamlarında, yaşlı meslektaşları ile birlikte çalışmayı isteyip istememe eğilimlerine bakılmıștır. Ayrıca katılımcıların yaşlı bakımı sorumluluğunun hangi kurumda olması gerektiğine ilișkin cevapları da analiz edilmiștir. Bu doğrultuda katılımcların verdikleri cevaplar ile onların YYTÖ ölçeğinden aldıkları puanların ortalaması arasındaki fark, bağımsız gruplar t-Testi ile analiz edilmiştir. Analiz sonuçları Tablo 5'de gösterilmiştir.

Tablo 5'de görüleceği üzere, örneklemi oluşturan gençlerin YYTÖ ölçeğinden aldıkları puan ortalamaları, okul sonrası meslek yaşamında 60 yaş ve üzeri bireyler ile çalışma arkadașı olmayı isteyip istememe değișkenine göre analiz edilmiştir. Bu amaçla gerçekleştirilen bağımsız gruplar t-Testi sonucunda gruplar arasındaki fark, istatistiksel olarak anlamlı bulunmuştur $(t=-2,16$; $\mathrm{p}=0,031 ; \mathrm{p}<0,05)$. Meslek yaşamında 60 yaș üstü bireyler ile çalışma arkadaşı olmak istemiyorum cevabı verenler daha yüksek bir puan ortalamasına sahiptir. Başka bir ifadeyle, meslek yaşamında yaşlılar ile birlikte çalışmak istiyorum cevabını verenlerin, istemiyorum cevabını verenlere oranla daha olumlu bir yașlılık ve yaşlanmaya ilişkin tutuma sahip olduğu tespit edilmiştir.

Ayrıca katılımcıların YYTÖ ölçeği puan ortalamalarının, yaşlı bakımında devlet ya da aile kurumlarından hangisinin sorumlu olması gerektiği sorusuna verdikleri cevaplara göre anlamlı bir farklılık gösterip göstermediği analiz edilmiştir. Tablo 5'de görüleceği üzere, bu amaç doğrultusunda gerçekleștirilen bağımsız gruplar t-Testi sonucuna göre, gruplar arasındaki fark istatistiksel olarak anlaml 
$p=0,027 ; p<0,05)$. Yaşlı bakımında sorumluluğun devlet kurumunda olması gerektiğini belirten katılımcıların, bu sorumluluğun aile kurumunda olması gerekti- ğini belirten katılımcılara oranla daha olumsuz bir yaşlllık ve yaşlanmaya ilişkin tutuma sahip olduğu tespit edilmiştir.

Tablo 5. YYTÖ Ölçeğinden alınan puanların, katılımcıların meslek yaşamında 60 yaş üstü bireyler ile çalışmayı isteyip istemedikleri ve yaşlı bakımı sorumluluğunun kimde olması gerektiği değişkenlerine göre farklılaşıp farklılaşmadığını belirlemek üzere yapılan bağımsız gruplar t-testi sonuçları

\begin{tabular}{|c|c|c|c|c|c|c|c|c|}
\hline \multirow[t]{2}{*}{ Puan } & \multirow{2}{*}{ Değişkenler } & \multirow{2}{*}{$\mathbf{N}$} & \multirow{2}{*}{$\overline{\mathbf{X}}$} & \multirow{2}{*}{ Ss } & \multirow{2}{*}{ Sx } & \multicolumn{3}{|c|}{ t Testi } \\
\hline & & & & & & $\mathrm{t}$ & Sd & p \\
\hline \multirow{6}{*}{$\begin{array}{l}\text { Yaşlılık ve Yaş- } \\
\text { lanmaya İlişkin } \\
\text { Tutum Ölçeği } \\
\text { (YYTÖ) }\end{array}$} & \multicolumn{8}{|c|}{60 Yaş Üstü Bireyle Birlikte Çalışmayı İsteyip, İstememe Durumu (N=634) } \\
\hline & Evet & 318 & 126,2 & 26,67 & 1,50 & $-2,16$ & 621,7 & $0,031^{*}$ \\
\hline & Hayır & 316 & 130,6 & 23,45 & 1,31 & & & \\
\hline & \multicolumn{8}{|c|}{ Yaşlı Bakımı Kimin Sorumluluğunda Olmalı $(\mathrm{N}=499)$} \\
\hline & Devlet & 128 & 132,7 & 25,15 & 2,22 & 2,21 & 626 & $0,027^{*}$ \\
\hline & Aile & 371 & 131,0 & 23,89 & 1,24 & & & \\
\hline
\end{tabular}

$* \mathrm{p}<0,05$

\section{TARTIŞMA}

Çalıșmada 19-24 yaș aralığındaki bir grup Y kușağına mensup gencin yaşlılık ve yaşlanmaya ilişkin tutumu tespit edilmiştir. Katılımcıların Yaşlılık ve Yaşlanmaya İlişkin Tutum Ölçeğinden (YYTÖ) ve bu ölçeğin alt boyutlarından aldıkları puan ortalamalarına bakılmıștır. Katılımcıların YYTÖ ölçeğinden aldıkları puanların, cinsiyet, yaşam yeri, aile tipi, büyük ebeveynler ile yaşama durumu, meslek yaşamında yaşlılar ile çalışmayı isteme durumu ve yașlı bakımı sorumluluğunun kimde olması gerektiğine ilişkin düşüncelerine göre değişiklik gösterip/göstermediğine bakılmıştır.

Araștırma sonuçları değerlendirildiğinde, araștırmaya katılanların yaşlılık ve yaşlanmaya ilişkin kısmen olumsuz bir tutuma sahip oldukları görülmektedir. Şahin ve Demirel (2018)'in gençlerin yaşlılık ve yaşlanmaya ilişkin tutumlarını ölçen çalışmasında da benzer sonuca ulaşılmıştır. Gençlerdeki bu olumsuz tutumun çeşitli nedenleri olabilir. Bu durum yaşlıların modern dönemde kaybettikleri sosyal statü ile açıklanabilir (Şentürk \& Ceylan, 2015). Zira yașlıların, modern dönemde toplumdaki statüleri zayıflamaktadır. Modern dönemde genç kalma ve üretken olabilme yüceltilmektedir. Gençliğin antitezi olarak görülen yașlılık olumsuz kavramlar ile inşa edilmektedir. Yaşlılığın sosyal inşası kuramına göre, yaşlılık her dönem sosyal ve kültürel faktörler ile inşa edilir. Modern dönemde yaşlılığa karşı geliştirilen fiziksel ve zihinsel yetersizlik algısında, bu inşa süreci etkilidir.

Parsons, Growing Old kitabına yazdığı önsözde, modern dönemde gençliğin yüceltildiğini, yaşlıların ise yetersizliklerinin ön plana çıkartıldığını belirtmektedir. Ayrıca kozmetik endüstrisi, yaşlı olmanın kötü ve istenmeyen bir durum olduğu fikrini sürekli canlı tutmaktadır. Müftüler (2018)'e göre günümüzde yaşlıların toplumsal imajları giderek kötüye gitmektedir. Modern dönemde inșa edilen bu genel olumsuz yașlı imajının, bireylerin yașlılık ve yașlanmaya ilișkin algılarını da olumsuz yönde etkilediği söylenebilir. 20. yüzyılın sonlarında doğan Y kuşağı da șüphesiz modern döneme hâkim olan olumsuz yaşlılık algısından etkilenmektedir. Bundan dolayı, Y kușağına mensup bireylerin yașlılık ve yașlanmaya ilișkin tutumlarının kendilerinden önceki kuşaklara göre bir miktar daha olumsuz olduğu söylenebilir. Diğer taraftan literatürde Türkiye'deki gençlerin yaşlılara karşı olumlu tutuma sahip olduğunu belirten çalışmalar da yer almaktadır (Kaçan, vd. 2018: 13; Adıbelli vd., 2013).

Bu çalışmada katılımcıların yaşlılık ve yaşlanmaya ilişkin tutumları ile cinsiyet arasında anlamlı bir fark bulunmamıştır. Literatürde benzer şekilde yaşlılara ilişkin olumsuz tutumların cinsiyete göre değişmediğini belirten çalışmalar yer almaktadır (Soyuer vd., 2010: 24; Özbek-Yazıcı, vd, 2015: 84; Çilingir vd., 2017: 139). Üniversite gençlerinin yaşlılık ve yaşlanmaya ilişkin tutumlarının cinsiyete göre değişmemesinde gençlerin zorunlu eğitim sürecinde eșit formasyona tabi olmalarının etkisinden söz edilebilir. Diğer taraftan literatürde, yaşlılara karşı tutumun cinsiyete göre değiștiğini belirten çalışmalar da bulunmaktadır (Güven vd., 2012; Ünsar vd., 2015; Altay \& Aydın, 2015; Dinçer vd., 2016; Ceylan \& Öksüz, 2015; Salman, vd., 2018; Kalınkara vd., 2019: 80).

Calıșmada katılımcıların sahip oldukları aile tipinin çekirdek ya da geniş aile olmasının yaşlılık ve yaşlanmaya ilișkin tutumlar üzerinde etkisi olmadığı tespit edilmiştir. Başka bir ifade ile katılımcıların sahip olduğu ailenin geniş ya da çekirdek aile olması yaşlılık ve yaşlanmaya ilișkin tutumlarını etkilememektedir. Benzer şekilde literatürde aile türünün yaşlılığa ve yaşlllara yönelik tutumları etkilemediğini bulgulayan çalıșmalara rastlanmıștır (Köse vd, 2015: 149; Altay ve Aydın, 2015; Salman, vd., 2018). Diğer taraftan katılımclların aile türü ile YYTÖ ölçeğinin "Yaşamla Baş Etme Zorluğu" ve "Olumsuz İmge" alt boyutları arasında istatistiksel olarak anlamlı bir fark tespit edilmiștir. Her iki alt boyuttan alınan puan ortalamaları, geleneksel geniş aile içinde doğan ve büyüyen katılımcılarda, çekirdek aile içinde doğup büyüyenlere göre daha yüksektir.

Çalışmada, katılımcıların doğup büyüdükleri yerleșim bölgesinin kır/köy ya da kent olmasının onların yaşlılık ve yaşlanmaya ilişkin tutumlarını etkilemediği görülmektedir. Literatürde benzer şekilde yaşam yeri bölgesinin yaşlılara ilișkin tutumu etkilemediğini belirten çalışmalar yer almaktadır (Çilingir vd., 2017; ÖzbekYazıcı vd., 2015; Dinçer vd., 2016; Boz vd., 2017; Sal- 
man, vd., 2018). Kitle iletişim araçları ve internet teknolojileri, kır ve kent yaşam yeri farklılıklarını ortadan kaldırmaktadır. Toplumdaki ana kültürün kır ve kent yerleșim bölgelerini kapsadığı ve bu bölgelerde benzerlik oluşturduğu söylenebilir. Benzer yaşam biçimlerinin kırda ya da kentte yaşayan gençlerdeki yaşlılık ve yaşlanmaya ilişkin tutumları da eşitlediği söylenebilir. $\mathrm{Bu}$ bulgu, yaşlılara kırda kente oranla daha fazla saygı duyulduğu ön kabulü ile çelişmektedir.

Bu çalışmada, ölçeğin "Yaşamla Baş Etme Zorluğu" alt boyutunun puan ortalamasının köy/kırda yașayan katılımcılarda, kentte yaşayan katılımcılardan daha yüksek olduğu tespit edilmiştir. Bunun anlamı, kırsal yaşamın zorluğu ile "Yaşamla Baş Etme Zorluğu" arasında bir ilișki olabileceğidir. Ayrıca kırdaki olumsuzlukların gençlerin algısını etkilediği düşünülebilir. Kente göre köy/kırda yaşamın daha zor olmasının, yaşlılık, yaşlanma ve yașamla baș edebilme zorluğu arasındaki ilișkiye dair algıyı pekiștirdiği söylenebilir.

Çalışmada katılımcıların büyük ebeveynler ile aynı evde yaşayıp yaşamama durumlarının, onların yaşlılık ve yașlanmaya ilișkin tutumlarını etkilemediği tespit edilmiştir. Literatürde benzer biçimde, büyük ebeveynleri ile aynı evde yașamanın yașlılığa dair tutumu etkilemediğini belirten çalışmalar bulunmaktadır (Özbek-Yazıcı vd., 2015; Ceylan ve Öksüz, 2015; Köse vd., 2015; Salman, vd., 2018). Diğer taraftan büyük ebeveynler ile birlikte yaşamanın yaşlılara dair tutumları olumsuz etkilediğini belirten çalıșmalar da bulunmaktadır (Dinçer vd., 2016; Yılmaz ve Özkan, 2010; Çilingir vd., 2017).

Ayrıca bu çalışmada, büyük ebeveynler ile birlikte aynı evde geçirilen sürenin yaşlılık ve yaşlanmaya ilişskin tutumu etkilediği tespit edilmiştir. Büyük ebeveynler ile aynı evde yaşama süresi arttıkça yaşlılığa ve yaşlanmaya ilişkin olumsuz tutum da artmaktadır.

Çalışmada, yaşlılık ve yaşlanmaya ilişkin daha olumlu bir tutuma sahip olan katılımcıların diğerlerine göre yașlılar ile daha fazla çalıșma arkadașı olmak istedikleri tespit edilmiştir. Ayrıca çalışmada, yaşlı bakımının kimin sorumluluğunda olması gerektiği sorusuna devlet cevabını verenlerin, aile cevabı verenlere oranla yaşlılık ve yaşlanmaya ilişkin tutumlarının daha olumsuz olduğu tespit edilmiștir.

\section{SONUC}

2060'lı yılların yaşlıları olacak Y kuşağı bireylerin yaşlı bakımı ile ilgili düșünce ve tutumları önemlidir. Kamunun sosyal politika anlayışı, yaşlı bakımında ailenin sorumluluğunun devam etmesi yönündedir. Ancak gençlerde yaşlı bakımı sorumluluğunun ailede olması gerektiği algısı ile yașlılık ve yașlanmaya ilișkin olumlu tutum doğru orantılıdır. Yașlılık ve yașlanmaya ilișkin tutum olumsuz olduğu oranda bireyler yaşlı bakımında devletten daha fazla beklentiye girmektedir/girecektir. Bu çerçevede çalışmaya katılan gençlerde özellikle yașlılara yönelik bir miktar olumsuz tutum dikkat çekicidir. Modernleşme sonrası inșa edilen genel olumsuz yaşlı imajının, 20. yüzyılın sonlarında doğan Y kuşağına mensup bu bireylerin yașlılık ve yașlanmaya ilișkin algılarını da olumsuz yönde etkilediği söylenebilir. Bu durumun bașta yașlı bakımında devletten beklentiler olmak üzere pek çok sosyal politika alanına etkisinin olacağı söylenebilir. Türkiye'de demografik yapıda yaşlıların oranının yüksek olacağı ön görülen 2050 ve sonrası dönemde yaşlı bakımı daha önemli bir hal alacaktır.

Bütün bu noktalar dikkate alınarak, Türkiye'nin 21 . yüzyılın ikinci yarısına dönük yaşlı bakımı ihtiyacı, nesnel veriler ile ortaya konulmalı ve söz konusu zaman dilimi için gerekli personel ve altyapı ihtiyacına dönük şimdiden hazırlıklar yapılmalıdır. Ayrıca Türkiye'de Y kuşağı bireylerin değer haritaları ile hayata ve yașlılığa bakışları üzerine daha fazla çalışma yapmaya ihtiyaç olduğu söylenebilir. Bu kușağın yașlılık algılarını daha olumluya dönüştürme sosyal politikanın temel gündemlerinden biri olmalıdır. Bunun için çeșitli eğitim ve seminer programları önerilebilir.

\section{KAYNAKCA}

Adıbelli, D., Türkoğlu, N., \& Kılıç, D. (2013). Öğrenci hemşirelerin yaşlılığa ilişkin görüşleri ve yaşlılığa karșı tutumları. Dokuz Eylül Üniversitesi Hemșirelik Yüksekokulu Elektronik Dergisi, 6(1), 2-8.

Altay, B., \& Aydın, T. (2015). Hemşirelik öğrencilerinin yaşlı ayrımcılığına ilişkin tutumlarının değerlendirilmesi. Hemşirelikte Eğitim ve Araştırma Dergisi, 12 (1), 11-18.

Bayhan, V. (2014). Milenyum veya (Y) kuşağı gençliğinin sosyolojik bağlamı. Gençlik Araștırmaları Dergisi, 2(2), 3, 8-25.

Boz, H., Gökçe, N., Özüstün Kıral, A., Mutlu, E., Selvi, N., Ünlü, D., \& Yılmaz, G. (2017). Sağlık Bilimleri Fakültesi ve İktisadi ve İdari Bilimler Fakültesi öğrencilerinin yașlı ayrımcılığına ilișkin tutumları. Kastamonu Sağlık Akademisi Dergisi, 2(1), 3254.

Ceylan, H., \& Öksüz, M. (2015). Sosyal hizmet lisans öğrencilerinin yaşlı ayrımcılığına ilişkin tutumlarınin incelenmesi. Journal of International Social Research, 8(39), 459-466.

Çilingir, D., Bulut, E., \& Hindistan, S. (2017). Hemşirelik bölümü öğrencilerinin yaşlı ayrımcılığına ilişkin tutumları. Dokuz Eylül Üniversitesi Hemșirelik Fakültesi Elektronik Dergisi, 10(3), 137-143.

Cockerham, W. C. (1991). This Aging Society. Englewood Cliffs, N. J.: Prentice Hall.

Cumming, E., \& Henry, W. E. (1961). Growing Old, the Process of Disengagement, New York: Basic Books.

Dinçer, Y., Usta, E., \& Bulduk, S. (2016). Üniversite öğrencileri gözüyle yașlılık nasıl algılanıyor? Yașlı Sorunları Araştırma Dergisi, 9(1), 26-38.

Güven, Ș. D., Ucakan-Muz, G., \& Efe-Ertürk, N. (2012). Üniversite öğrencilerinin yaşlı ayrımcılığına ilişkin tutumları ve bu tutumların bazı değişkenlerle ilișkisi. Anadolu Hemșirelik ve Sağlık Bilimleri Dergisi, 15(2), 99-105.

Kaçan, H., Dibekli, E., \& Akkan K. (2018). Toplumda yaşayan bireylerin yaşlı ayrımcılığı tutum düzeylerinin incelenmesi. Yașlı Sorunları Araștırma Dergisi, 11(2), 8-15.

Kalınkara, V., Günay, G., Boylu, A. A., Şahin, H., Arpacı, F., Ay, F., vd., (2019). Farklı alanlarda öğrenim gören üniversite öğrencilerinin yaşlı ayrımcılığına yönelik tutumlarının belirlenmesi. Yașlı Sorunları Araștırma Dergisi, 12(2), 73-83. 
Karasar, N. (1998). Bilimsel Arastırma Yöntemi: Kavramlar, Ilkeler, Teknikler, Ankara: Nobel Yayın Dağıtım.

Kökalan-Çımrın, F. (2009). Küreselleşme, neoliberalizm ve refah devleti ilișkisi üzerine, Muğla Üniversitesi Sosyal Bilimler Enstitüsü Dergisi. 23, 195-203.

Köse, G., Ayhan, H., Taștan, S., İyigün, E., \& Hatipoğlu, S. (2015). Sağlık alanında farklı bölümlerde öğrenim gören öğrencilerin yașlı ayrımcılığına ilişkin tutumlarının belirlenmesi. Gülhane Tıp Dergisi, $57,145-151$.

Kurtkapan, H. (2018). Kentte Yaşlılık ve Yerel Yönetim Uygulamaları. Ankara: Nobel Yayıncılık.

Kurtkapan, H. (2019). Ünal Șentürk, yașlllık sosyolojisi, yaşlılığın toplumsal yörüngeleri. Insan ve Toplum Dergisi 9(4), 166-168.

Moody, H. R., \& Sasser, J. R. (2012). Aging: Concepts and Controversies, 7th ed. Los Angeles, Sage.

Morgan, L. A., \& Kunkel, S. (2007). Aging: Society and the Life Course. 3rd ed. New York: Springer.

Müftüler, H. G. (2018). Modern toplumda yaș ve yașlı ayrımcılı̆̆ı. Türkiye Sosyal Hizmet Araștırmaları Dergisi, 2 (2), 181-184.

Otrar, M. (2016). Yaşlılık ve yaşlanmaya ilişkin tutum ölçeği: geçerlilik ve güvenirlik çalıșması. Sosyoloji Dergisi, 36 (2), 527-550.

Özbek-Yazıcı, S., Kalaycı, I., Kaya, E., \& Tekin, A. (2015). Yaşlı bakım programı öğrencilerinin yaşlı ayrımcılığına ilişkin tutumları. Yaş̧ı Sorunlarını Araştırma Dergisi, (2), 77-87.

Phillipson, C. \& Baars, J. (2007). Social teory and social ageing, ageing. in (eds.) Bond, J., Peace, s., Dittmann-Kohli, F. \& Westerhof, G. Society: European Perspectives on Gerontology, (pp. 68-84), $3^{\text {rd }}$ edition, Los Angeles: Sage.

Riley. M. W. (1976). Social gerontology and the age stratification of society. in (eds.) Atchley, R. C. \& Seltzer, M. M, The Sociology of Aging: Selected Readings, Belmont, Calif: Wadsworth Pub. Co.

Salman, M., Gülçek, E., Aylaz, R., \& Polat, F. (2018). Hemşirelik öğrencilerinin yaşlılara karşı tutumlarının değerlendirilmesi. Yaşlı Sorunları Araştırma Dergisi, 11 (2), 1-7.
Şahin, H., \& Demirel, B. (2018). Sosyal hizmet bölümü öğrencilerinin yaşlılık ve yaşlanmaya ilişkin tutumlarının belirlenmesi. Uluslararası Sosyal Araştırmalar Dergisi, 11 (59), 1114- 1120.

Șentürk M., \& Ceylan, H. (2015). Ístanbul'da Yașlanmak ve Yaşlıların Mevcut Durumu Araştırması. İstanbul: Açlım Kitapevi.

Soyuer, F., Ünalan, D., Güleser, N., \& Elmalı, F. (2010). Sağlık meslek yüksekokulu öğrencilerinin yaşlı ayrımcılığına ilişkin tutumları ve bu tutumların bazı demografik değişkenlerle ilişkisi. Mersin Üniversitesi Sağlık Bilimleri Dergisi, 3(2), 20-25.

Turner, B. S. (2011). Tıbbi Güç ve Toplumsal Bilgi. (Çev.) Tatlıcan, Ü., İstanbul: Sentez Yayıncılık.

Türkiye İstatistik Kurumu, (TÜIK), (2018). Nüfus projeksiyonları, 2018-2080, (Çevrimiçi) http//www.tuik.gov.tr/PreHaberBultenleri.do?id=30567 adresinden 19.08.2019 tarihinde erişilmiştir.

United Nations Department of Economic and Social Affairs [UNDESA] (2015). World Population Ageing 2015 (ST/ESA/SER.A/390). New York: United Nations.

Ünsar, S., Erol, Ö., Kurt, S., Türüng, F., Dinlegör Sekmen, I., Sak, C., \& Türksen, S. (2015). Hemşirelik öğrencilerinin yaşlı ayrımcılığına ilişkin tutumlarının incelenmesi. Cumhuriyet Hemşirelik Dergisi, 4(2), 61-67.

Victor, C. R. (2005). The Social Context of Aging. New York, Routledge, 2005.

Westerhof, G. J., \& Tulle, E. (2007). Meaning of ageing and old age: Discursive contexts, social attitudes and personal identities. in (eds.) Bond, J., Peace \& S., Dittmann-Kohli, F., Ageing in Society: European Perspectives on Gerontology, (pp. s. 235254), 3rd ed., Gerben Westerhof, Los Angeles: Sage.

Yılmaz, E., \& Özkan, S. (2010). Hemşirelik öğrencilerinin yaşlı ayrımcılığına ilişkin tutumları. Maltepe Üniversitesi Hemşirelik Bilim ve Sanat Dergisi, 3(2), 35-53. 